Prepared for $\mathrm{CH} 2 \mathrm{M}$ HILL Plateau Remediation Company

and the U.S. Department of Energy

under Contract DE-AC05-76RL01830

\title{
Revised Geostatistical Analysis of the Inventory of Carbon Tetrachloride in the Unconfined Aquifer in the 200 West Area of the Hanford Site
}

\section{CJ Murray \\ Y-J Bott}

\section{December 2008}

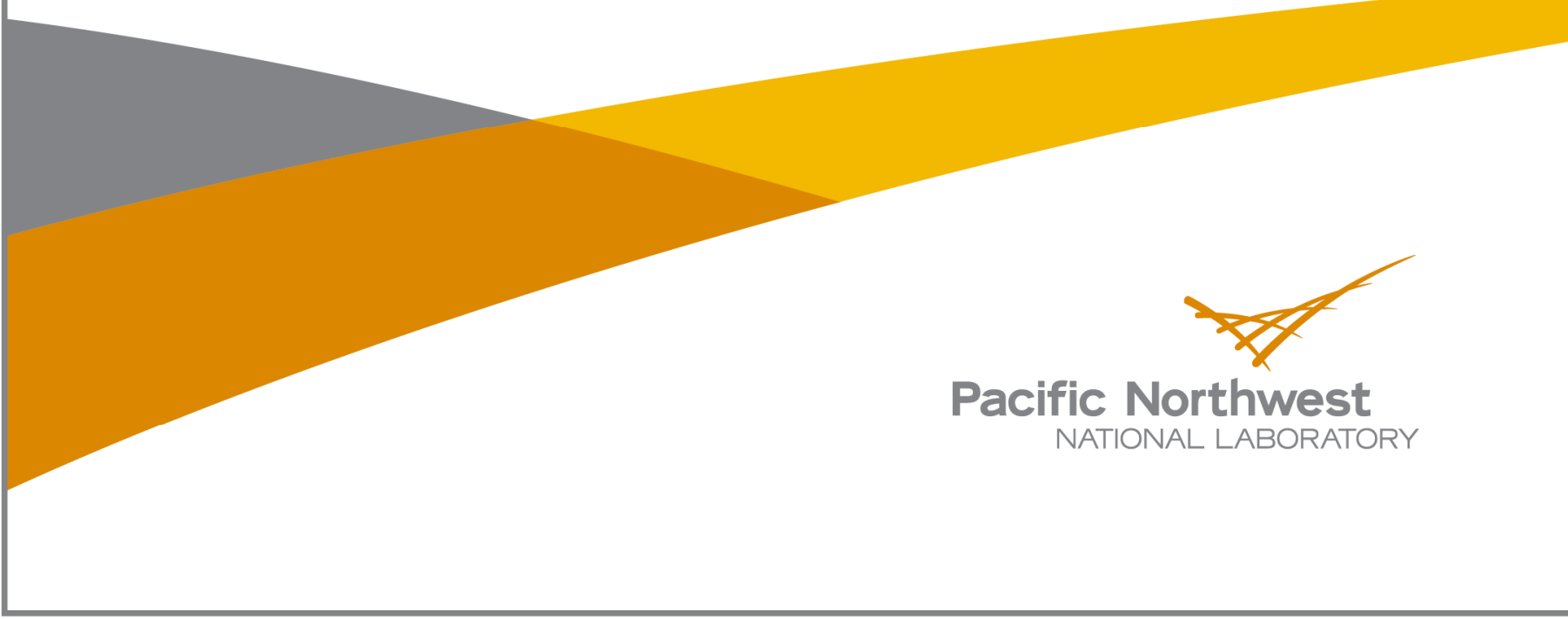




\title{
DISCLAIMER
}

This report was prepared as an account of work sponsored by an agency of the United States Government. Neither the United States Government nor any agency thereof, nor Battelle Memorial Institute, nor any of their employees, makes any warranty, express or implied, or assumes any legal liability or responsibility for the accuracy, completeness, or usefulness of any information, apparatus, product, or process diselosed, or represents that its use would not infringe privately owned rights. Reference herein to any specific commercial product, process, or service by trade name, trademark, manufacturer, or otherwise does not necessarily constitute or imply its endorsement, recommendation, or favoring by the United States Government or any agency thereof, or Battelle Memorial Institute. The views and opinions of authors expressed herein do not necessarily state or reflect those of the United States Government or any agency thereof.

\author{
PACIFIC NORTHWEST NATIONAL LABORATORY \\ operated by \\ BATTELLE \\ for the \\ UNITED STATES DEPARTMENT OF ENERGY \\ under Contract DE-AC05-76RL01830
}

Printed in the United States of America

Available to DOE and DOE contractors from the Office of Scientific and Technical Information,

P.O. Box 62, Oak Ridge, TN 37831-0062; ph: (865) 576-8401 fax: $(865) 576-5728$

email: reports@adonis.osti.gov

\author{
Available to the public from the National Technical Information Service, \\ U.S. Department of Commerce, 5285 Port Royal Rd., Springfield, VA 22161 \\ ph: (800) 553-6847 \\ fax: $(703) 605-6900$ \\ email: orders@ntis.fedworld.gov \\ online ordering: http://www.ntis.gov/ordering.htm
}

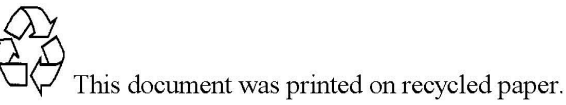

(9/2003) 


\title{
Revised Geostatistical Analysis of the Inventory of Carbon Tetrachloride in the Unconfined Aquifer in the 200 West Area of the Hanford Site
}

\author{
CJ Murray \\ Y-J Bott
}

December 2008

Prepared for

CH2M HILL Plateau Remediation Company

and the U.S. Department of Energy

under Contract DE-AC05-76RL01830

Pacific Northwest National Laboratory

Richland, Washington 99352 



\section{Summary}

This report provides an updated estimate of the inventory of carbon tetrachloride (CTET) in the unconfined aquifer in the 200 West Area of the Hanford Site. The contaminant plumes of interest extend within the 200-ZP-1 and 200-UP-1 operable units. CH2M HILL Plateau Remediation Company (CHPRC) currently is preparing a plan identifying locations for groundwater extraction wells, injection wells, transfer stations, and one or more treatment facilities to address contaminants of concern identified in the 200-ZP-1 CERCLA Record of Decision. To accomplish this, a current understanding of the inventory of CTET is needed throughout the unconfined aquifer in the 200 West Area.

Pacific Northwest National Laboratory (PNNL) previously developed an estimate of the CTET inventory in the area using a Monte Carlo approach based on geostatistical simulation of the threedimensional (3D) distribution of CTET and chloroform in the aquifer. Fluor Hanford, Inc. (FH) (the previous site contractor) requested PNNL to update that inventory estimate using as input a set of geostatistical realizations of CTET and chloroform recently created for a related but separate project, referred to as the mapping project. The scope of work for the inventory revision complemented the scope of work for the mapping project, performed for FH by PNNL through contract release 27647-344, PNNL to Complete Spatial Analyses of Contaminants at the 200 West Area in Support of the 200 ZP-1 PreConceptual Remedy Design, and documented in PNNL-18100.

A database of depth-discrete data for contaminants of interest in the unconfined aquifer in the 200 West Area was developed for the mapping project, with all data traceable back to the original data sources, e.g., the Hanford Environmental Information System. The CTET and chloroform data used to generate the geostatistical realizations that form the basis for the inventory estimates were obtained from that database. This report briefly describes the spatial and univariate distribution of the CTET and chloroform data, along with the results of the geostatistical analysis and simulation performed for the mapping project.

The inventory of CTET and chloroform were estimated within the geostatistical simulation grid using a Monte Carlo approach. The inventory reflects CTET and chloroform present in the groundwater and sorbed to the sediment, with the chloroform assumed to represent CTET that degraded early. The inventory simulations were based solely on aqueous concentration data from the two data sets and do not include the mass of any CTET that might be present as a dense non-aqueous phase liquid. The Monte Carlo approach used to estimate the inventory attempted to account for uncertainty in the porosity and the sediment/water equilibrium partition coefficient $\left(\mathrm{K}_{\mathrm{d}}\right)$ values for CTET and chloroform by drawing values for those parameters from probability distributions.

A suite of 500 values of the estimated CTET inventory in the unconfined aquifer was generated from the 500 simulations of CTET and chloroform concentrations. The average total mass of CTET estimated to be present in the study area over the 500 realizations was $120,093 \mathrm{~kg}$. Of this amount, the vast majority (99.0\%) was found in cells with a simulated aqueous concentration of at least $5 \mu \mathrm{g} / \mathrm{L}$, and $95.1 \%$ was found in cells with aqueous concentrations of at least $100 \mu \mathrm{g} / \mathrm{L}$. Analysis of intermediate results used to generate the total mass numbers indicates that $52.8 \%$ of the total mass is due to the aqueous concentration of CTET in groundwater, $43.2 \%$ is from CTET assumed to be sorbed to the aquifer sediment, and $4.0 \%$ is from chloroform. The 500 realizations of the total mass have a reasonably 
symmetric distribution, with $95 \%$ of the simulated total mass values falling within a range from $88,074 \mathrm{~kg}$ to $160,379 \mathrm{~kg}$. CTET inventory results also are broken out individually for the 200-ZP-1 and 200-UP-1 operable units.

The estimated mass of CTET present in the aquifer was converted to estimates of the total amount of CTET that would have been present originally in the aquifer in order to account for the current inventory, assuming that abiotic degradation had taken place since the CTET originally entered the aquifer, with an assumed average entry date of 1973 . The resulting estimate of the total amount of CTET represented by the inventory estimates suggests that approximately $160,000 \mathrm{~kg}$ of CTET would need to have entered the aquifer to account for the current estimate of the existing inventory in the aquifer.

The average value of the total mass of CTET generated for the current study, $120,092.5 \mathrm{~kg}$, is a $10.3 \%$ increase over the average total mass of CTET reported by the authors for the previous estimate of the CTET inventory, which was $108,868.5 \mathrm{~kg}$. Two main factors appear to be responsible for that increase. One is the difference in data used to condition the stochastic simulations of CTET and chloroform that form the basis for the inventory estimates. Several new wells were drilled and added to the data set since the previous estimates were made. Some of those (e.g., wells 299-W11-88 and 699-4369) were in the northeastern part of the study area where no well control existed and found relatively high concentrations of CTET. The second factor is the difference in variogram models used to generate the stochastic simulations of CTET and chloroform, especially for CTET. The 3D variogram model used as the default case for the current study has a higher relative nugget and longer vertical range than the variogram model used in the previous estimates. 


\section{Acknowledgments}

The authors thank Matt Tonkin (S.S. Papadopulos \& Associates, Inc.); Mark Byrnes and Virginia Rohay (CH2M HILL Plateau Remediation Company); and Paul Thorne (Pacific Northwest National Laboratory) for their cooperation and collaboration on the performance of this project. We also acknowledge Charlotte Sullivan, who provided a technical review of the report, and Andrea Currie, who provided editorial support for the document. 



\title{
Acronyms and Abbreviations
}

\author{
$2 \mathrm{D}$ \\ two-dimensional \\ $3 \mathrm{D}$ \\ three-dimensional \\ BWT \\ below water table \\ CERCLA \\ Comprehensive Environmental Response, Compensation, and Liability Act of \\ 1980 \\ CHPRC \\ CH2M HILL Plateau Remediation Company \\ COI \\ contaminant of interest \\ CTET \\ carbon tetrachloride \\ DBWT \\ depth below water table \\ DNAPL \\ dense nonaqueous phase liquid \\ DOE \\ U.S. Department of Energy \\ $\mathrm{FH}$ \\ Fluor Hanford, Inc. \\ FY \\ fiscal year \\ $\mathrm{K}_{\mathrm{a}}$ \\ abiotic degradation rate due to hydrolysis \\ $\mathrm{K}_{\mathrm{d}}$ \\ sediment/water equilibrium partition coefficient \\ OU \\ operable unit \\ PNNL \\ Pacific Northwest National Laboratory \\ SSPA \\ S.S. Papadopulos \& Associates, Inc. \\ VET \\ Vista Engineering Technology, LLC
}





\section{Contents}

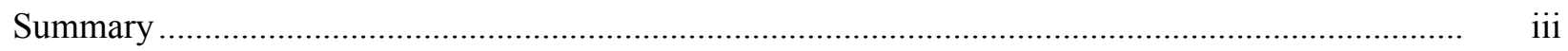

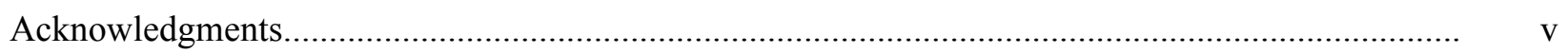

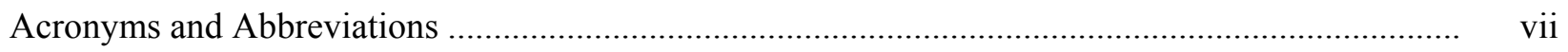

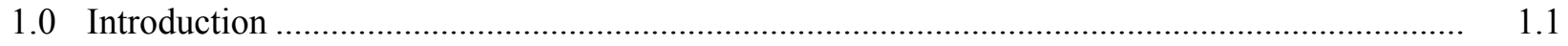

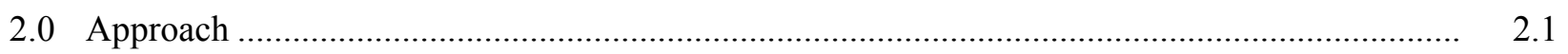

2.1 Development of Depth-Discrete Database for Carbon Tetrachloride and

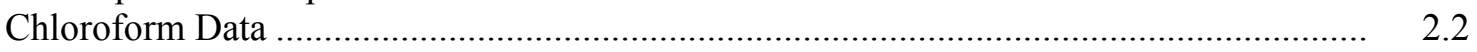

2.2 Distribution of Carbon Tetrachloride and Chloroform Data ........................................... 2.3

2.3 Geostatistical Analysis and Simulation....................................................................... 2.4

2.4 Inventory Estimation Process......................................................................................... 2.7

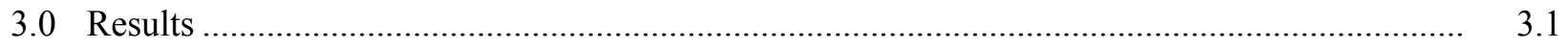

3.1 Estimated Total Mass of CTET Present in the Study Area ............................................. 3.1

3.2 Estimated Mass of CTET Present in the 200-ZP-1 Operable Unit .................................... 3.2

3.3 Estimated Mass of CTET Present in the 200-UP-1 Operable Unit .................................... 3.2

3.4 Estimated Mass of CTET Present Before Abiotic Degradation .......................................... 3.4

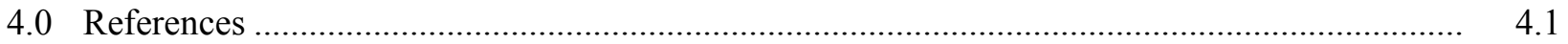




\section{Figures}

2.1 Map of Study Area Showing Outlines of Sub-Areas Used for Inventory Estimates .................. 2.1

2.2 Median CTET Concentration of Simulations Based on the 3D Variogram Model ..................... 2.5

2.3 Median CTET Concentration of Simulations Based on the Variogram Model of

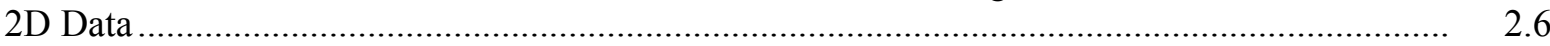

2.4 Median Simulated Chloroform Concentration over 500 Realizations ..................................... 2.6

2.5 Comparison of Global Average CTET Concentrations for Realizations Generated Using the 3D and 2D Variogram Models .......................................................................... 2.7

3.1 Total Mass of CTET Calculated from the Simulations of CTET Concentrations Based on the 3D Variogram Model ................................................................................. 3.2

3.2 Estimated Mass of CTET in the 200-ZP-1 Operable Unit ...................................................... 3.3

3.3 Estimated Mass of CTET in the 200-UP-1 Operable Unit ........................................................ 3.4

\section{Tables}

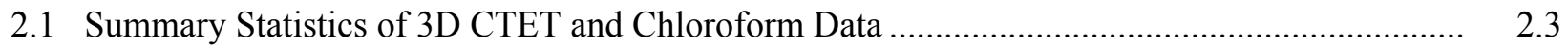

2.2 Number of Wells Within Depth Intervals for CTET and Chloroform...................................... 2.3

2.3 Variogram Models Fit to the CTET and Chloroform Normal Score Data ............................... 2.4

2.4 Grid Parameters Used in Generation of the Geostatistical Realizations.................................... 2.5

3.1 Summary Statistics of Inventory of Total Mass and the Mass of CTET Partitioned

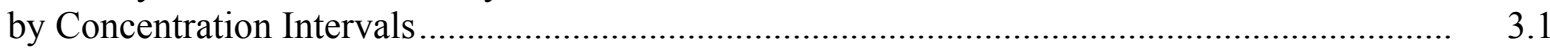

3.2 Summary Statistics of Inventory of Total Mass and Mass of CTET in the 200-ZP-1 Operable Unit Partitioned by Concentration Intervals of CTET ….......................................... 3.3

3.3 Summary Statistics of Inventory of Total Mass and Mass of CTET in the 200-UP-1 Operable Unit Partitioned by Concentration Intervals of CTET ............................................. 3.4

3.4 Summary Statistics of Estimated Original Total Mass of CTET Present in the Aquifer Before Its Abiotic Degradation over Time by Hydrolysis 


\subsection{Introduction}

This report provides an updated estimate of the inventory of carbon tetrachloride (CTET) in the unconfined aquifer in the 200 West Area of the Hanford Site. The contaminant plumes of interest extend within the 200-ZP-1 and 200-UP-1 operable units (OUs). CH2M HILL Plateau Remediation Company (CHPRC) currently is preparing a plan identifying locations for groundwater extraction wells, injection wells, transfer stations, and one or more treatment facilities to address contaminants of concern identified in the 200-ZP-1 CERCLA Record of Decision. To accomplish this, a current understanding of the inventory of CTET is needed throughout the unconfined aquifer in the 200 West Area.

Pacific Northwest National Laboratory (PNNL) previously developed an estimate of the CTET inventory in the area using a Monte Carlo approach based on geostatistical simulation of the threedimensional (3D) distribution of CTET and chloroform in the aquifer (Murray et al. 2007). Fluor Hanford, Inc. (FH) (the previous site contractor) requested that PNNL update that inventory estimate using as input a set of geostatistical realizations of CTET and chloroform recently created for a related but separate project (Murray and Bott 2008), referred to in this report as the mapping project. The scope of work for the inventory revision complemented the scope of work performed for FH by PNNL through contract release 27647-344, PNNL to Complete Spatial Analyses of Contaminants at the 200 West Area in Support of the 200 ZP-1 Pre-Conceptual Remedy Design.

In this report, Section 2 describes the approach used for generation of the inventory estimates. The results of the estimation process are presented in Section 3. A list of references cited in the report is included in Section 4. 



\subsection{Approach}

The approach used to generate the revised inventory estimate closely follows that of Murray et al. (2007). The grid resolution and origin used for the CTET and chloroform simulations differ slightly from those used by Murray et al. (2007). They were modified to fit the needs of a concurrent flow and transport modeling effort using the results of the mapping study to provide 3D input grids for the spatial distribution of the contaminants of interest (COIs) within the unconfined aquifer in the 200 West Area and surrounding areas (M. J. Tonkin, SSPA, personal communication, 2008). For the current study, we used a $60-\mathrm{m}$ x $60-\mathrm{m}$ grid in the horizontal and a $3-\mathrm{m}$ vertical resolution. The simulation grid extended to a depth of $60 \mathrm{~m}$ below the top of the water table. Figure 2.1 shows the location of the study area and the outline of two sub-areas used for generation of the estimates. The boundaries of the northern portion of

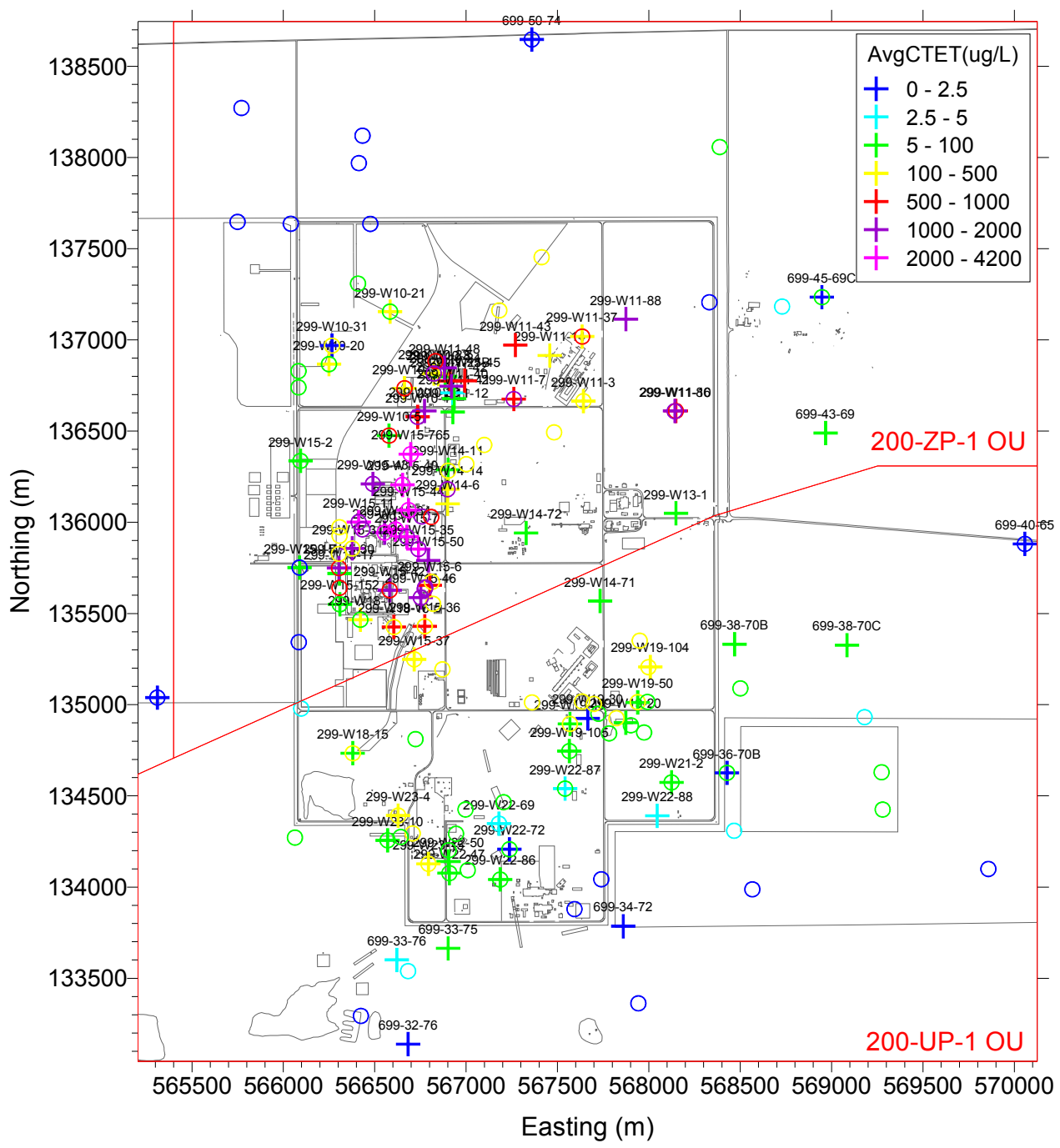

Figure 2.1. Map of Study Area Showing Outlines of Sub-Areas Used for Inventory Estimates. Locations of depth-discrete CTET data are shown (crosses), as are the locations of 2D data from the FY 2007 groundwater monitoring report (circles). 
the area were used to generate inventory estimates for the 200-ZP-1 OU, and the southern portion of the area was used to generate inventory estimates for the 200-UP-1 OU. The total estimate reflects the sum of the estimates for the two sub-areas.

The stochastic simulations of CTET and chloroform used to generate the revised inventory estimates were generated for the mapping project, and details of the data and spatial and geostatistical analysis that form the basis for those simulations are described in a separate report (Murray and Bott 2008). For completeness, a brief summary of the methodology and results of the mapping project are presented here.

\subsection{Development of Depth-Discrete Database for Carbon Tetrachloride and Chloroform Data}

A Microsoft Access database developed for the mapping project includes all relevant depth-discrete data on the distribution of CTET and chloroform, as well as other COIs, in the study area (Murray and Bott 2008). Data sets from several sources were included in the database: the 200-ZP-1 Remedial Investigation data set; the 200-ZP-1 Feasibility Study data set; depth-discrete CTET and chloroform data sets evaluated by V. J. Rohay at CHPRC; and a retrieval of the most recent data available in the Hanford Environmental Information System. In addition to the 3D depth-discrete concentration data, the database was supplemented by including the two-dimensional (2D) data sets used to map CTET and chloroform in the FY 2007 groundwater monitoring report (Hartman and Webber 2008). The use of the supplemental 2D data sets follows the approach taken by Murray et al. (2007) in which the 2D data were used as supplemental data for variogram analysis when sufficient depth-discrete data were not available to define the horizontal variogram. The 2D data were used also as supplemental data in the geostatistical mapping to provide additional constraints on the concentrations present near the water table.

Non-detect concentrations in the database were replaced by one-half their stated value, a common practice in environmental analysis (Gilbert 1987). On occasion, more than a single observation of the concentration was made at a given 3D location (e.g., duplicate samples from a single depth in a well). When this occurred, the maximum concentration value that was above detection was used to represent the concentration at that location. If all data from a given location were less than the detection limit, then one-half the minimum value would be used. This decision was made because some instruments and laboratories have lower detection limits than others, and the minimum non-detect result would be expected to be more representative of the true concentration.

Depth of each sample was established relative to the water table, and all subsequent analysis was performed based on the depth below the water table (DBWT). Murray and Bott (2008) describe the procedures and assumptions used to establish the well and sample elevations, the elevation of the water table, and the DBWT for each sample.

Several criteria were used in selection of the depth-discrete COI data for use in the spatial analysis and geostatistical mapping tasks. These included sampling date and geographic area. The data were restricted so that concentration data collected from only 1999 or later were included in the final data used for analysis and mapping. The vast majority of the data incorporated in the final data set used for mapping were from 2003 or later. The data were geographically restricted to lie between easting coordinates of $564000 \mathrm{~m}$ and $572200 \mathrm{~m}$ and northing coordinates of $132850 \mathrm{~m}$ and $139300 \mathrm{~m}$ (Washington State plane coordinates). This provided data coverage that extended slightly beyond the limits of the grid that was mapped using geostatistical methods. 
The concentration and activity values summarized in the resulting tables of the Microsoft Access database generated for the mapping project are considered final for CTET and chloroform and were used in the spatial analysis and geostatistical mapping conducted for the mapping project.

\subsection{Distribution of Carbon Tetrachloride and Chloroform Data}

In mapping the spatial distribution of the contaminants, 436 depth-discrete CTET data and 422 chloroform data were used (Table 2.1). Section 3 of Murray and Bott (2008) provides a detailed description of the univariate and spatial distribution of the depth-discrete CTET and chloroform data. Both CTET and chloroform are strongly skewed, with mean concentration values much higher than the median concentrations. The number of depth-discrete CTET and chloroform data decrease with depth (Table 2.2), but even at depths of 50-60 m below the water table there are 18 well locations with data available. Figure 2.1 gives the location of 3D depth-discrete data in the upper $10 \mathrm{~m}$ of the aquifer, plus locations where estimates of the CTET concentration at the water table were available from the FY 2007 groundwater monitoring report (Hartman and Webber 2008).

Table 2.1. Summary Statistics of $3 D$ CTET and Chloroform Data

\begin{tabular}{lcc}
\hline & \multicolumn{2}{c}{ Contaminant of Interest } \\
\cline { 2 - 3 } \multicolumn{1}{c}{ Statistic } & CTET & $\begin{array}{c}\text { Chloroform } \\
(\mu \mathrm{g} / \mathrm{L})\end{array}$ \\
\hline Mean & 729.72 & 42.86 \\
Standard error & 48.55 & 5.99 \\
Median & 211.50 & 11.00 \\
Standard deviation & 1013.78 & 123.08 \\
Sample variance & 1027745.53 & 15149.86 \\
Coefficient of variation & 1.39 & 2.87 \\
Kurtosis & 2.64 & 36.06 \\
Skewness & 1.73 & 5.57 \\
Range & 5099.93 & 1099.97 \\
Minimum & 0.08 & 0.04 \\
Maximum & 5100.00 & 1100.00 \\
Count & 436 & 422 \\
\hline
\end{tabular}

Table 2.2. Number of Wells Within Depth Intervals for CTET and Chloroform

\begin{tabular}{lcccccc}
\hline \multicolumn{1}{c}{ COI } & $0-10 \mathrm{~m}$ & $10-20 \mathrm{~m}$ & $20-30 \mathrm{~m}$ & $30-40 \mathrm{~m}$ & $40-50 \mathrm{~m}$ & $50-60 \mathrm{~m}$ \\
\hline CTET & 80 & 52 & 42 & 37 & 20 & 18 \\
Chloroform & 77 & 49 & 40 & 33 & 19 & 18 \\
\hline
\end{tabular}




\subsection{Geostatistical Analysis and Simulation}

The CTET and chloroform data described in Section 2.2 were used as the basis for generation of numerical grids of the concentration of CTET and chloroform. Multiple realizations were created using a geostatistical simulation approach known as sequential Gaussian simulation (Goovaerts 1997; Deutsch and Journel 1998). That approach is based on use of a normal score transform of the data that transforms the data so that they are normally distributed with a mean of zero and a variance of 1 . This transform, which is similar in its effect to a logarithmic transform, adjusts for the positively skewed nature of the COI concentrations but has several advantages over a logarithmic transform. The depth-discrete data for both CTET and chloroform were converted to normal scores (Goovaerts 1997), and experimental variograms were calculated in three dimensions. Horizontal (2D) variograms were calculated also for the normal scores of the CTET and chloroform data sets compiled for the FY 2007 annual groundwater report (Hartman and Webber 2008). Table 2.3 contains a summary of the models fit to the experimental variograms. Details on the modeling and plots of the variograms can be found in Murray and Bott (2008).

Table 2.3. Variogram Models Fit to the CTET and Chloroform Normal Score Data

\begin{tabular}{cccccc}
\hline & & & & \multicolumn{2}{c}{ Range (m) } \\
\cline { 5 - 6 } COI & Nugget & Sill & Structure & Horizontal & Vertical \\
\hline CTET (3D) & 0.40 & 0.60 & Spherical & 800 & 50 \\
CTET (2D) & 0.08 & 0.92 & Spherical & 1650 & 30 \\
Chloroform & 0.17 & 0.83 & Spherical & 1250 & 70 \\
\hline
\end{tabular}

Table 2.3 identifies two different variogram models for CTET. The 3D model is based on fitting models to the horizontal and vertical experimental variograms calculated for the depth-discrete data. The 2D model is based on the variogram calculation and modeling procedure employed for the previous estimate of the CTET inventory (Murray et al. 2007). In that estimate, the horizontal variogram was fit to the variogram of the FY 2007 annual groundwater monitoring report data (Hartman and Webber 2008), and the range of the vertical variogram was assumed to be $30 \mathrm{~m}$ based on the apparent thickness of the CTET plume.

For the current study, we used a $60-\mathrm{m}$ x $60-\mathrm{m}$ grid in the horizontal and a $3-\mathrm{m}$ vertical resolution. The simulation grid extended to a depth of $60 \mathrm{~m}$ below the top of the water table. The vertical thickness of the simulation grid was chosen for two reasons. One is that the average thickness of the unconfined aquifer in the study area is approximately $60 \mathrm{~m}$ (Williams et al. 2005). In addition, the number of CTET data decreases with increasing depth below the top of the aquifer, as shown in Table 2.2; below a depth of $60 \mathrm{~m}$, only two to four data points were present in each 10-m interval. The parameters of the grid are given in Table 2.4, with a total of 167,328 grid nodes in the 3D grid.

Five hundred realizations of the CTET concentration were retained for both variogram models, and the same number of realizations was retained for chloroform. Plots of the median simulated CTET value at each grid node for the 3D and 2D models are shown in Figures 2.2 and 2.3, with the median simulated value of the chloroform realizations shown in Figure 2.4. Additional figures displaying the simulation results for both variables may be found in Murray and Bott (2008). 
Table 2.4. Grid Parameters Used in Generation of the Geostatistical Realizations

\begin{tabular}{cccccc}
\hline & Minimum $(\mathrm{m})$ & Maximum $(\mathrm{m})$ & $\begin{array}{c}\text { Length } \\
(\mathrm{m})\end{array}$ & Spacing $(\mathrm{m})$ & Number \\
\hline $\mathrm{X}$ & 565205 & 570125 & 4920 & 60 & 83 \\
$\mathrm{Y}$ & 133045 & 138745 & 5700 & 60 & 96 \\
$\mathrm{Z}$ & -60 & 0 & 60 & 3 & 21 \\
\hline
\end{tabular}

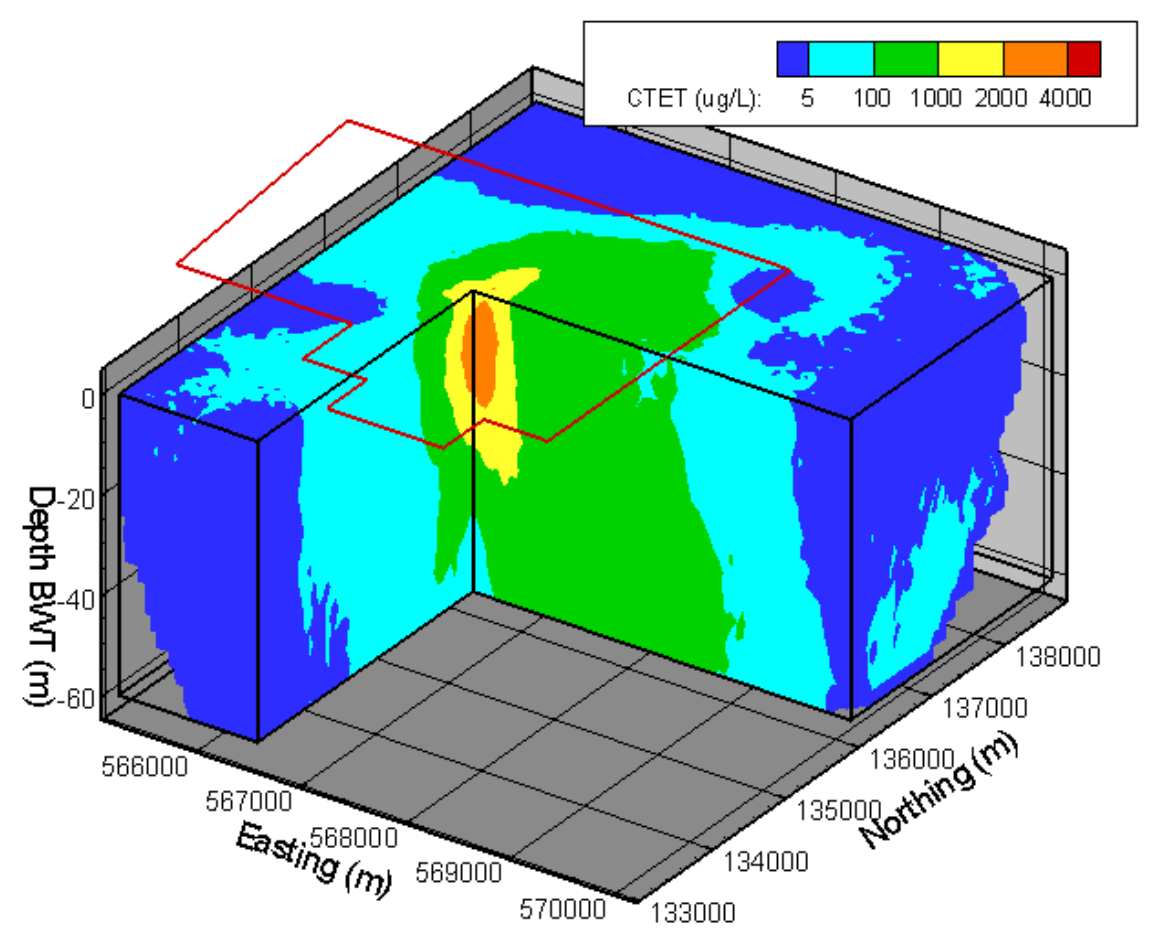

Figure 2.2. Median CTET Concentration of Simulations Based on the 3D Variogram Model. Cutaway at easting from $566525 \mathrm{~m}$ to $570125 \mathrm{~m}$ and northing from $133045 \mathrm{~m}$ to $135985 \mathrm{~m}$. The red line outlines the 200 West Area. 


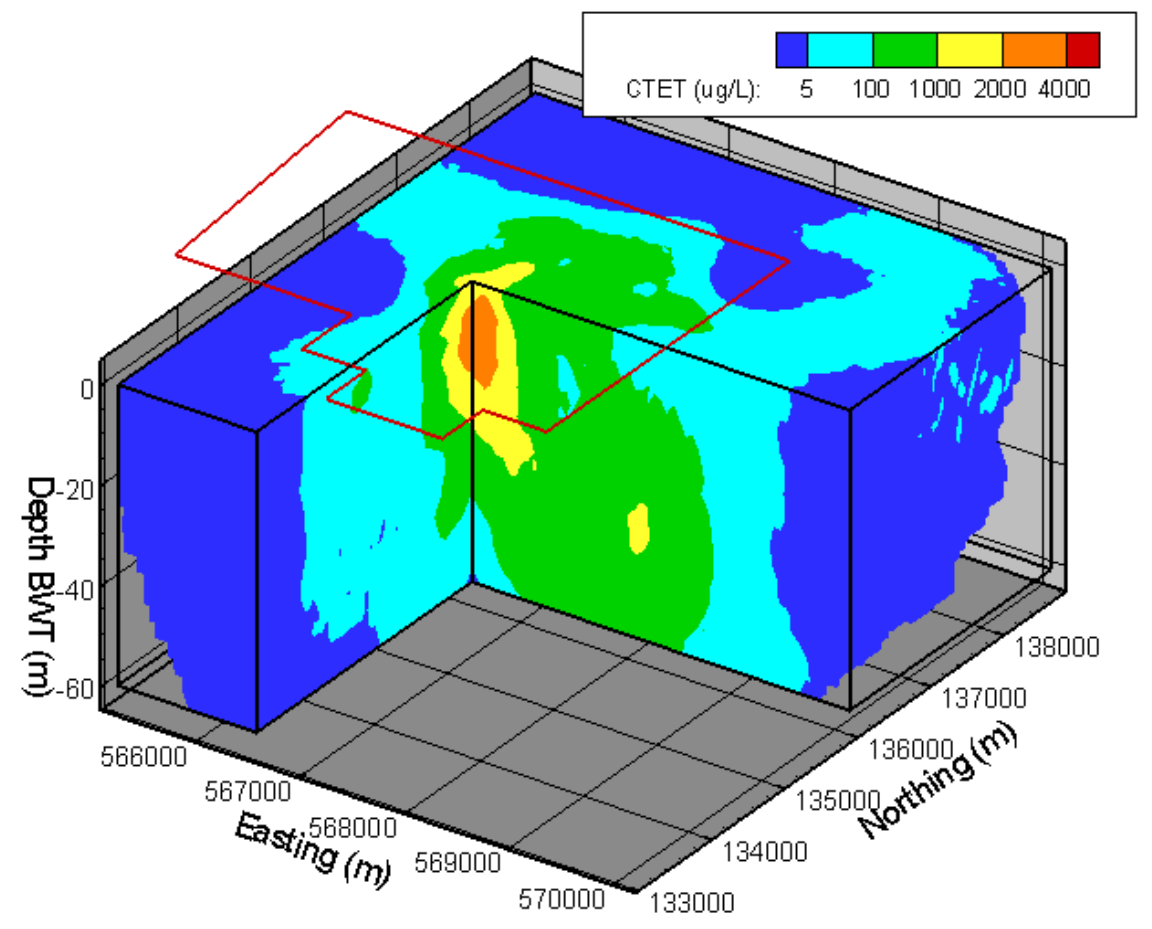

Figure 2.3. Median CTET Concentration of Simulations Based on the Variogram Model of 2D Data. Cutaway at easting from $566525 \mathrm{~m}$ to $570125 \mathrm{~m}$ and northing from $133045 \mathrm{~m}$ to $135985 \mathrm{~m}$.

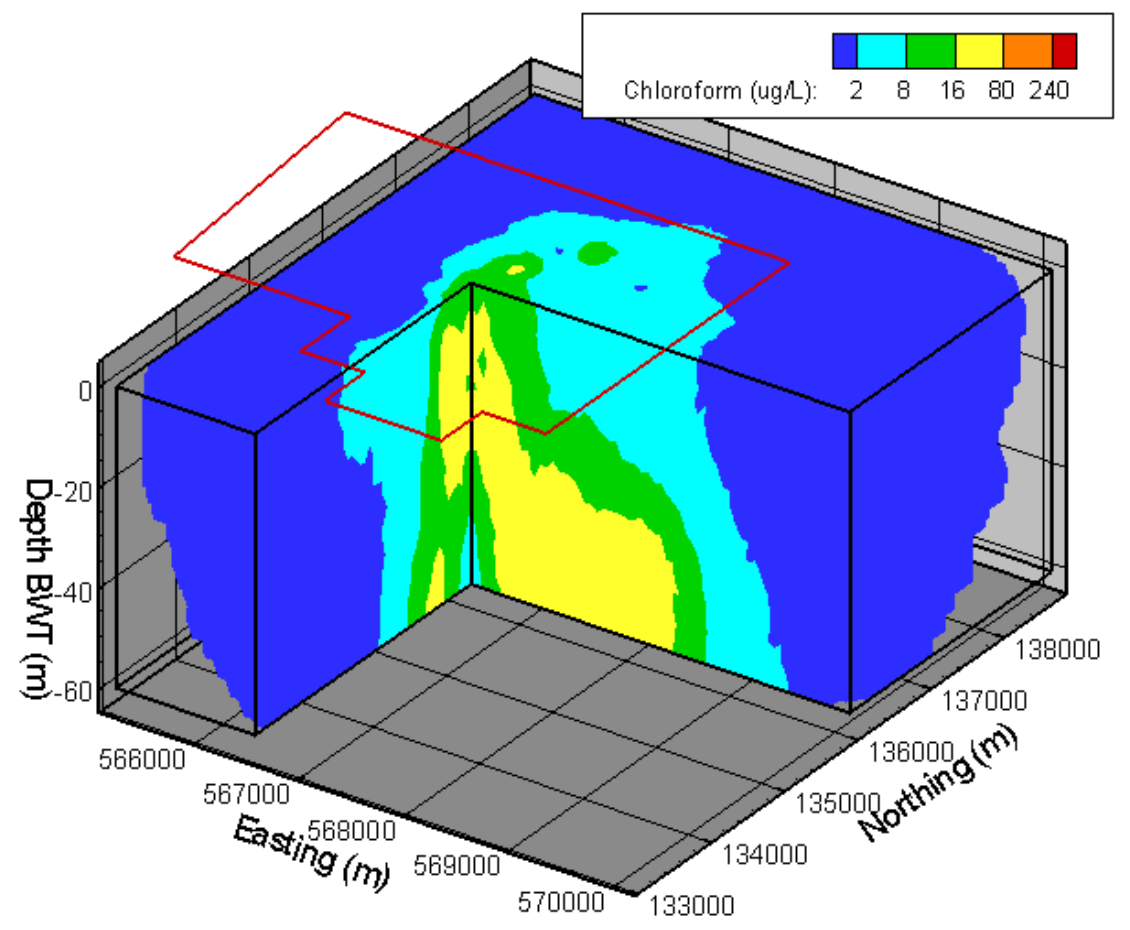

Figure 2.4. Median Simulated Chloroform Concentration over 500 Realizations. Cutaway at easting from $566525 \mathrm{~m}$ to $570125 \mathrm{~m}$ and northing from $133045 \mathrm{~m}$ to $135985 \mathrm{~m}$. 
Analysis of several different statistics of the simulated concentrations for each realization (e.g., Figure 2.5) showed that the 3D model tended to produce higher CTET concentrations than the 2D model. That difference suggests that the 3D model would provide a conservative (i.e., higher) estimate of the CTET concentrations. For that reason, and because the 3D variogram model was calculated directly for the depth-discrete data, the realizations generated using the 3D variogram model were retained as the base case for further analysis. The inventory estimates for CTET included in this report are based on the stochastic simulations of CTET generated using the 3D variogram model.

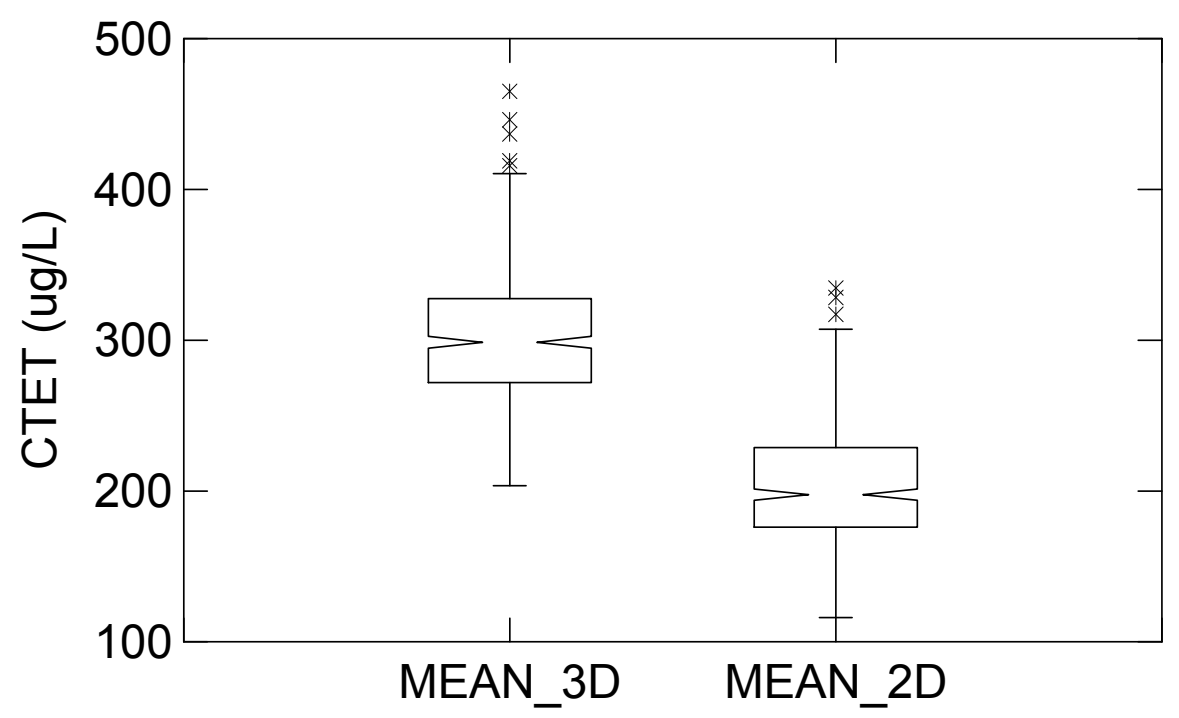

Figure 2.5. Comparison of Global Average CTET Concentrations for Realizations Generated Using the 3D and 2D Variogram Models. The medians of the distributions are shown as the center of the notches, and the lower and upper quartiles as the bottom and top of the boxes, respectively. The notches represent an approximate $95 \%$ confidence interval around the median (McGill et al. 1978). Asterisks represent outlier data points at 1.5 and 3.0 times the interquartile range, respectively.

\subsection{Inventory Estimation Process}

The process employed for estimation of the inventory is based on the approach used by Murray et al. (2007, Appendix). For the current study, the 500 simulations of CTET and chloroform discussed in Section 2.3 were post-processed using a Monte Carlo approach to provide a suite of 500 estimates of the inventory of CTET and the uncertainty in the estimated CTET inventory. For each simulation of CTET and chloroform, the mass of CTET in each cell of the 3D grid was calculated. The simulations were performed over a rectangular 3D grid with a vertical thickness of $60 \mathrm{~m}$. In some places within the study area, the unconfined aquifer is less than $60 \mathrm{~m}$ thick, so we used a grid of aquifer thickness (P. D. Thorne, PNNL, personal communication, 2006) to identify grid nodes that were deeper than the base of the unconfined aquifer and deleted the simulated inventory values associated with those grid nodes from the total inventory. Portions of the 3D grid where data were extremely sparse were blanked during the simulation process or before the calculation of the inventory. At the request of personnel from SSPA (M. J. Tonkin, SSPA, personal communication, 2008), estimates of the CTET inventory for 200-ZP-1 and 
200-UP-1 were calculated and reported separately, in addition to the total inventory for the 200 West Area and surrounding area that had been reported by Murray et al. (2007). The outlines for 200-ZP-1 and 200-UP-1 were digitized from a shape file provided by M. J. Tonkin of SSPA (see Figure 2.1). Note that the far western edge of the grid in the area of 200-ZP-1 was not included in the outline of the 200-ZP-1 OU due to the conclusion that concentrations between 5 and $100 \mu \mathrm{g} / \mathrm{L}$ shown at the western edge of the area (e.g., Figure 2.2) were caused by the lack of constraint on the western edge of the plume in that area (Murray and Bott 2008). Therefore, those values at the extreme western edge of the grid but beyond the boundary provided by SSPA were not included in the inventory estimates.

The estimated mass is based entirely on the dissolved aqueous concentrations and does not include the mass of any CTET that might be present as a dense nonaqueous phase liquid (DNAPL). The total mass calculated for the inventory included the mass of CTET in the groundwater and the mass of CTET sorbed to sediment, as well as the mass of CTET assumed to have degraded to chloroform and now present in the groundwater and sorbed to the sediment as chloroform. A molecular weight ratio of 1.3 was used to convert chloroform mass to CTET mass (Murray et al. 2007, Appendix)

The porosity of each cell was drawn from a Gaussian distribution with a mean of 0.13 and a standard deviation of 0.033 . This is the probability distribution for the Ringold Formation porosity assumed by Murray et al. (2004). Values of Ringold porosity in a range from 0.08 to 0.14 were cited also by Szecscody et al. (2005), Thorne et al. (2006), and Oostrom et al. (2006, 2007). The statement of work for the inventory revision proposed that a sensitivity estimate be generated using a higher estimate of porosity for the Ringold aquifer. However, it was discovered during the performance of the analysis that porosities significantly higher than those used previously would violate the assumptions made by the approach developed by Murray et al. (2007, Appendix), leading to the calculation of unrealistic values for the mass of fines in each grid cell. In order to investigate the effect of higher porosities on CTET inventories, it would be necessary to develop a modified approach for simulating the total porosity and the mass of fine-grained material in the sediments.

The sediment/water equilibrium partition coefficients $\left(\mathrm{K}_{\mathrm{d}} \mathrm{s}\right)$ for CTET and chloroform were used to estimate the amount of CTET and chloroform sorbed to the sediment in each cell, with the assumption that the CTET and chloroform were sorbed to the fine-grained sediment in the cell. As assumed by Murray et al. (2007), the $K_{d}$ values for each simulation for CTET and chloroform were based on Riley et al. (2005). The $K_{d}$ values in that study are desorption $K_{d} s$ that are significantly higher than the $K_{d} S$ reported by Cantrell et al. (2003) and by Wellman et al. (2007). One cause for the low $\mathrm{K}_{\mathrm{d}}$ estimates found by Wellman et al. (2007) and other recent investigators appears to be the short contact times employed in those studies, which are appropriate for use in reactive transport models in which CTET is exposed to the sediments for a brief period of time. However, given the approach in this study, which requires estimation of the amount of CTET that may have sorbed to the sediments over long periods (contact of sediment and contaminated groundwater in excess of 30 years in some portions of the aquifer), the use of the Riley et al. (2005) desorption $\mathrm{K}_{\mathrm{d}}$ estimates appears to be reasonable (D. Wellman, PNNL, personal communication, 2008). The maximum and minimum $\mathrm{K}_{\mathrm{d}}$ for CTET and chloroform were used to estimate the maximum and minimum parameters for triangular probability distributions, with the most probable value for the distributions set to the average of the minimum and maximum. For the inventory calculations, 500 values were drawn from the $\mathrm{K}_{\mathrm{d}}$ probability distributions, one for each simulation.

The total CTET associated with each cell was accumulated for each simulation to arrive at a total current CTET inventory for each simulation. The 500 simulated CTET inventory values provide the basis 
for an estimate of the inventory and the uncertainty associated with that estimate. In addition, the amount of the CTET inventory associated with several contour intervals (CTET concentrations of 5-100 $\mu \mathrm{g} / \mathrm{L}$, $100-1000 \mu \mathrm{g} / \mathrm{L}, 1000-4000 \mu \mathrm{g} / \mathrm{L}$, and $>4000 \mu \mathrm{g} / \mathrm{L}$ ) was calculated for each simulation.

The effect of hydrolysis, which transforms CTET directly to $\mathrm{CO}_{2}$, on the CTET that originally entered the aquifer was estimated also, based on several assumptions. According to Truex et al. (2001), the disposal of CTET took place from 1955 to 1973. Oostrom et al. (2004) indicate that the average time for transport of CTET to the aquifer was 9 years, so we assumed the majority of the CTET entered the aquifer between 1964 and 1982. We assumed an average date of CTET entry into the aquifer of 1973, at which time degradation of the CTET by hydrolysis began. Thus, it was assumed that CTET entered the aquifer and began degradation 31 years or 11,315 days before 2004 (used as the representative date of depthdiscrete CTET data collection). Truex et al. (2001) provide the parameters for a triangular probability distribution for the abiotic degradation rate due to hydrolysis $\left(\mathrm{K}_{\mathrm{a}}\right)$, assuming a minimum half-life of 36 years, a maximum half-life of 290 years, and a most probable half-life of 100 years. We drew 500 values of $\mathrm{K}_{\mathrm{a}}$ from that probability distribution, used those values to estimate the original mass of CTET that entered the aquifer by applying the $\mathrm{K}_{\mathrm{a}}$ value to the CTET currently present in the aquifer (i.e., not including CTET that degraded to chloroform), and then added that to the amount of CTET that degraded to chloroform. 



\subsection{Results}

This section presents the results of the revised CTET inventory estimates based on the 500 geostatistical simulations of CTET and chloroform generated by Murray and Bott (2008) from the 3D variogram model and the porosity, $\mathrm{K}_{\mathrm{d}}$, and $\mathrm{K}_{\mathrm{a}}$ distributions described in Section 2.4. The mass results are presented first for the total study area defined in Figure 2.1, then for two sub-areas, the 200-ZP-1 and 200-UP-1 OUs. As described in Section 2.4, the mass results incorporate the mass of CTET in the groundwater and the mass of CTET assumed to be sorbed to sediment, as well as the mass of CTET assumed to have degraded to chloroform and now present in the groundwater and sorbed to the sediment as chloroform. After the results for the individual OUs are presented, the results of the mass of aqueous CTET assumed to have originally entered the aquifer before abiotic degradation are presented.

\subsection{Estimated Total Mass of CTET Present in the Study Area}

The average total mass of CTET estimated to be present in the study area over the 500 realizations, including both 200-ZP-1 and 200-UP-1, was 120,093 kg (Table 3.1). Of this amount, the vast majority $(99.0 \%)$ was found in cells with a simulated aqueous concentration of at least $5 \mu \mathrm{g} / \mathrm{L}$, and $95.1 \%$ was found in cells with aqueous concentrations of at least $100 \mu \mathrm{g} / \mathrm{L}$ (Table 3.1). Analysis of intermediate results used to generate the total mass numbers in Table 3.1 indicates that $63,358.2 \mathrm{~kg}(52.8 \%)$ of the total mass is due to the aqueous concentration of CTET in groundwater, $51,918.1 \mathrm{~kg}(43.2 \%)$ is from CTET assumed to be sorbed to the aquifer sediment, and 4,816.2 $\mathrm{kg}(4.0 \%)$ is from chloroform. A histogram of the total mass estimates shows that the 500 realizations of the total mass have a reasonably symmetric distribution, with $95 \%$ of the simulated total mass values falling within a range from $88,074 \mathrm{~kg}$ to $160,379 \mathrm{~kg}$ (Figure 3.1).

Table 3.1. Summary Statistics of Inventory of Total Mass and the Mass of CTET Partitioned by Concentration Intervals for the Entire Study Area. CTET mass calculated from the geostatistical simulations based on the 3D variogram model.

\begin{tabular}{|c|c|c|c|c|c|c|}
\hline \multirow[b]{2}{*}{ Statistic } & \multicolumn{6}{|c|}{ Carbon Tetrachloride (kg) } \\
\hline & Total Mass & $\begin{array}{c}5-100 \\
\mu \mathrm{g} / \mathrm{L}\end{array}$ & $\begin{array}{c}100-1000 \\
\mu \mathrm{g} / \mathrm{L}\end{array}$ & $\begin{array}{c}1000-2000 \\
\mu \mathrm{g} / \mathrm{L}\end{array}$ & $\begin{array}{c}2000-4000 \\
\mu \mathrm{g} / \mathrm{L}\end{array}$ & $\begin{array}{r}>4000 \\
\mu \mathrm{g} / \mathrm{L}\end{array}$ \\
\hline Mean & $120,092.5$ & 4574.0 & $31,740.5$ & $41,540.5$ & $37,242.4$ & 3743.0 \\
\hline Standard error & 811.5 & 20.9 & 163.1 & 278.7 & 352.1 & 65.1 \\
\hline Median & $118,661.9$ & 4529.1 & $31,776.2$ & $41,067.5$ & $36,253.8$ & 3450.4 \\
\hline Standard deviation & $18,146.1$ & 467.3 & 3646.3 & 6232.0 & 7872.5 & 1455.6 \\
\hline Kurtosis & 0.4 & 0.2 & -0.1 & 0.2 & 0.7 & 10.3 \\
\hline Skewness & 0.5 & 0.4 & 0.1 & 0.4 & 0.7 & 2.1 \\
\hline Range & $109,695.9$ & 2889.1 & $21,626.2$ & $39,534.6$ & $52,553.3$ & $14,422.8$ \\
\hline Minimum & $73,821.3$ & 3367.1 & $22,440.8$ & $25,492.0$ & $17,508.0$ & 1136.1 \\
\hline Maximum & $183,517.2$ & 6256.2 & $44,067.0$ & $65,026.6$ & $70,061.3$ & $15,558.8$ \\
\hline Count & 500 & 500 & 500 & 500 & 500 & 500 \\
\hline
\end{tabular}




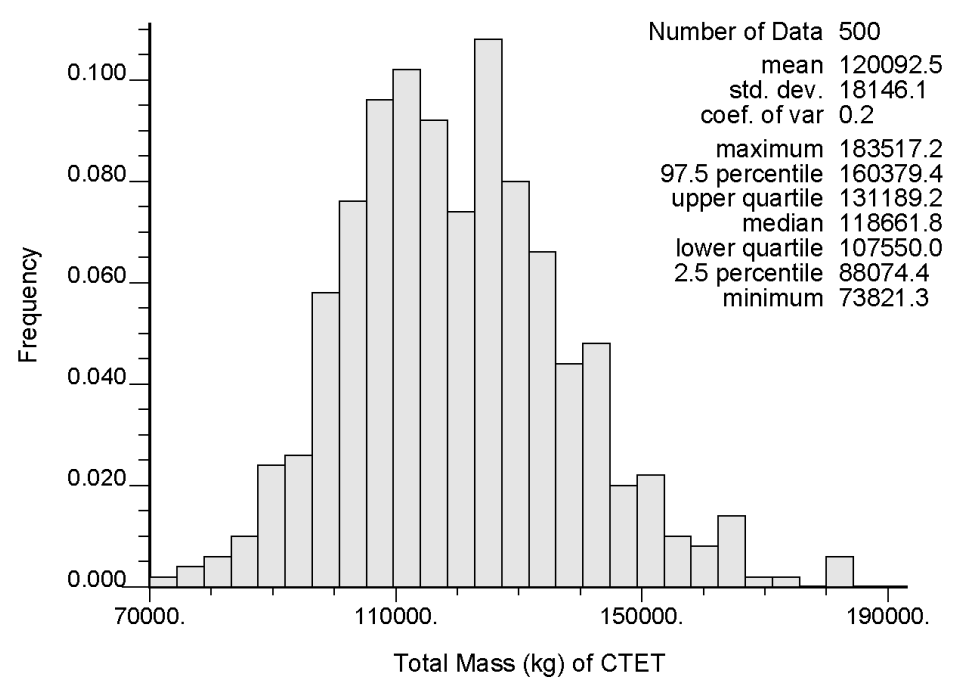

Figure 3.1. Total Mass of CTET in the Entire Study Area Calculated from the Simulations of CTET Concentrations Based on the 3D Variogram Model

The average value of the total mass of CTET generated for the current study, $120,092.5 \mathrm{~kg}$ (Figure 3.1), is a 10.3\% increase over the average total mass of CTET reported for the previous estimate of the CTET inventory, which was $108,868.5 \mathrm{~kg}$ (Murray et al. 2007, Table 2.6). Two main factors appear to be responsible for that increase. One is the difference in data used to condition the stochastic simulations of CTET and chloroform that form the basis for the inventory estimates. Several new wells were drilled and added to the data set since the previous estimates were made. Some of the new wells (e.g., 299-W11-88 and 699-43-69) were in the northeastern part of the study area (where no well control existed) and found relatively high concentrations of CTET. The second factor is the difference in variogram models used to generate the stochastic simulations of CTET and chloroform, especially for CTET. The 3D variogram model used as the default case for the current study has a higher relative nugget and longer vertical range than the variogram model used in the previous estimates.

\subsection{Estimated Mass of CTET Present in the 200-ZP-1 Operable Unit}

The average mass of CTET within the 200-ZP-1 OU was $80,979.2 \mathrm{~kg}$ (Table 3.2), which is $67.4 \%$ of the average simulated mass of $120,092.5 \mathrm{~kg}$ for the entire study area. Again, the vast majority of the CTET mass occurs in cells with a simulated aqueous CTET concentration of at least $5 \mu \mathrm{g} / \mathrm{L}$, and $95.9 \%$ was found in cells with aqueous concentrations of at least $100 \mu \mathrm{g} / \mathrm{L}$ (Table 3.2). Figure 3.2 shows that $95 \%$ of the simulated CTET mass values for the ZP-1 area fell between $56,308.5 \mathrm{~kg}$ and $111,141.9 \mathrm{~kg}$.

\subsection{Estimated Mass of CTET Present in the 200-UP-1 Operable Unit}

The average mass of CTET within the 200-UP-1 OU was less than that in the ZP-1 OU, at 39,113.3 $\mathrm{kg}$ (Table 3.3), which is $32.6 \%$ of the average simulated mass of $120,092.5 \mathrm{~kg}$ for the entire study area. Figure 3.3 shows that $95 \%$ of the simulated CTET mass values for the UP-1 area fell between $25,205.3 \mathrm{~kg}$ and $56,289.3 \mathrm{~kg}$. 
Table 3.2. Summary Statistics of Inventory of Total Mass and Mass of CTET in the 200-ZP-1 Operable Unit Partitioned by Concentration Intervals of CTET. Calculated from the 500 simulations generated using the 3D variogram model.

\begin{tabular}{lrrrrrr}
\hline & \multicolumn{5}{c}{ Carbon Tetrachloride $(\mathrm{kg})$} \\
\cline { 2 - 7 } \multicolumn{1}{c}{ Statistic } & Total Mass & $\begin{array}{c}5-100 \\
\mu \mathrm{g} / \mathrm{L}\end{array}$ & $\begin{array}{c}100-1000 \\
\mu \mathrm{g} / \mathrm{L}\end{array}$ & $\begin{array}{c}1000-2000 \\
\mu \mathrm{g} / \mathrm{L}\end{array}$ & $\begin{array}{c}2000-4000 \\
\mu \mathrm{g} / \mathrm{L}\end{array}$ & $\begin{array}{c}>4000 \\
\mu \mathrm{g} / \mathrm{L}\end{array}$ \\
\hline Mean & $80,979.2$ & 2579.2 & $19,165.1$ & $27,760.4$ & $27,687.5$ & 3053.6 \\
Standard error & 629.7 & 15.2 & 108.5 & 208.1 & 293.3 & 58.2 \\
Median & $79,396.3$ & 2533.6 & $19,067.5$ & $27,402.3$ & $26,613.1$ & 2792.9 \\
Standard deviation & $14,081.2$ & 341.0 & 2425.7 & 4652.2 & 6559.4 & 1301.7 \\
Kurtosis & 0.9 & 0.6 & 0.1 & 0.5 & 1.3 & 15.1 \\
Skewness & 0.6 & 0.7 & 0.2 & 0.5 & 0.8 & 2.6 \\
Range & $94,833.4$ & 2059.9 & $15,332.3$ & $31,345.3$ & $45,330.9$ & $13,895.9$ \\
Minimum & $46,205.3$ & 1796.4 & $12,291.3$ & $16,082.2$ & $12,082.9$ & 897.7 \\
Maximum & $141,038.8$ & 3856.3 & $27,623.5$ & $47,427.5$ & $57,413.8$ & $14,793.6$ \\
Count & 500 & 500 & 500 & 500 & 500 & 500 \\
\hline
\end{tabular}

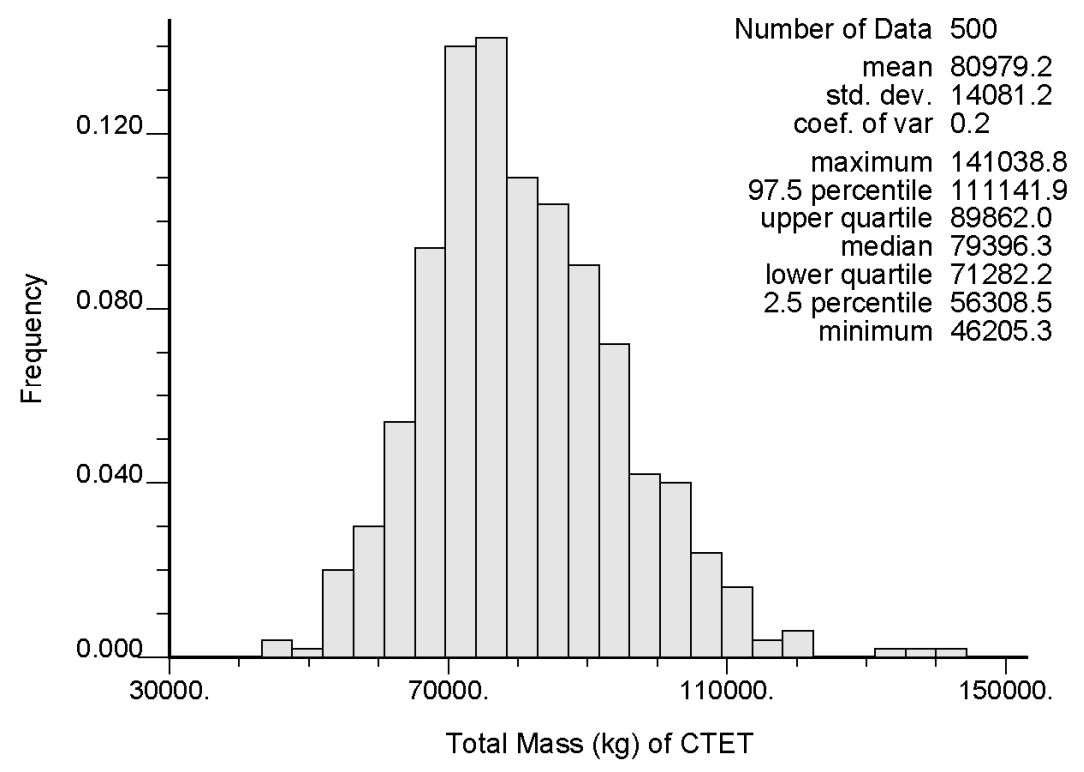

Figure 3.2. Estimated Mass of CTET in the 200-ZP-1 Operable Unit. Calculated from the simulations of CTET concentration based on the 3D variogram model. 
Table 3.3. Summary Statistics of Inventory of Total Mass and Mass of CTET in the 200-UP-1 Operable Unit Partitioned by Concentration Intervals of CTET. Calculated from the 500 simulations generated using the 3D variogram model.

\begin{tabular}{lcccccc}
\hline & \multicolumn{5}{c}{ Carbon Tetrachloride $(\mathrm{kg})$} \\
\cline { 2 - 6 } \multicolumn{1}{c}{ Statistic } & Total Mass & $\begin{array}{r}5-100 \\
\mu \mathrm{g} / \mathrm{L}\end{array}$ & $\begin{array}{c}100-1000 \\
\mu \mathrm{g} / \mathrm{L}\end{array}$ & $\begin{array}{c}1000-2000 \\
\mu \mathrm{g} / \mathrm{L}\end{array}$ & $\begin{array}{c}2000-4000 \\
\mu \mathrm{g} / \mathrm{L}\end{array}$ & $\begin{array}{c}>4000 \\
\mu \mathrm{g} / \mathrm{L}\end{array}$ \\
\hline Mean & $39,113.3$ & 1994.8 & $12,575.4$ & $13,780.1$ & 9554.9 & 689.4 \\
Standard error & 358.6 & 9.6 & 84.1 & 131.5 & 139.5 & 21.1 \\
Median & $38,180.2$ & 1973.2 & $12,377.5$ & $13,464.3$ & 8952.0 & 555.6 \\
Standard deviation & 8017.8 & 214.1 & 1880.0 & 2940.0 & 3118.5 & 471.0 \\
Kurtosis & -0.3 & 0.1 & -0.5 & -0.3 & 0.2 & 4.6 \\
Skewness & 0.4 & 0.3 & 0.2 & 0.4 & 0.7 & 1.9 \\
Range & $41,256.0$ & 1252.0 & 9424.8 & $15,468.2$ & $16,093.9$ & 3260.9 \\
Minimum & $22,849.6$ & 1451.4 & 8508.3 & 7624.6 & 3712.2 & 60.1 \\
Maximum & $64,105.7$ & 2703.5 & $17,933.1$ & $23,092.8$ & $19,806.1$ & 3321.1 \\
Count & 500 & 500 & 500 & 500 & 500 & 500 \\
Confidence level of & 704.5 & 18.8 & 165.2 & 258.3 & 274.0 & 41.4 \\
mean (95.0\%) & & & & & \\
\hline
\end{tabular}

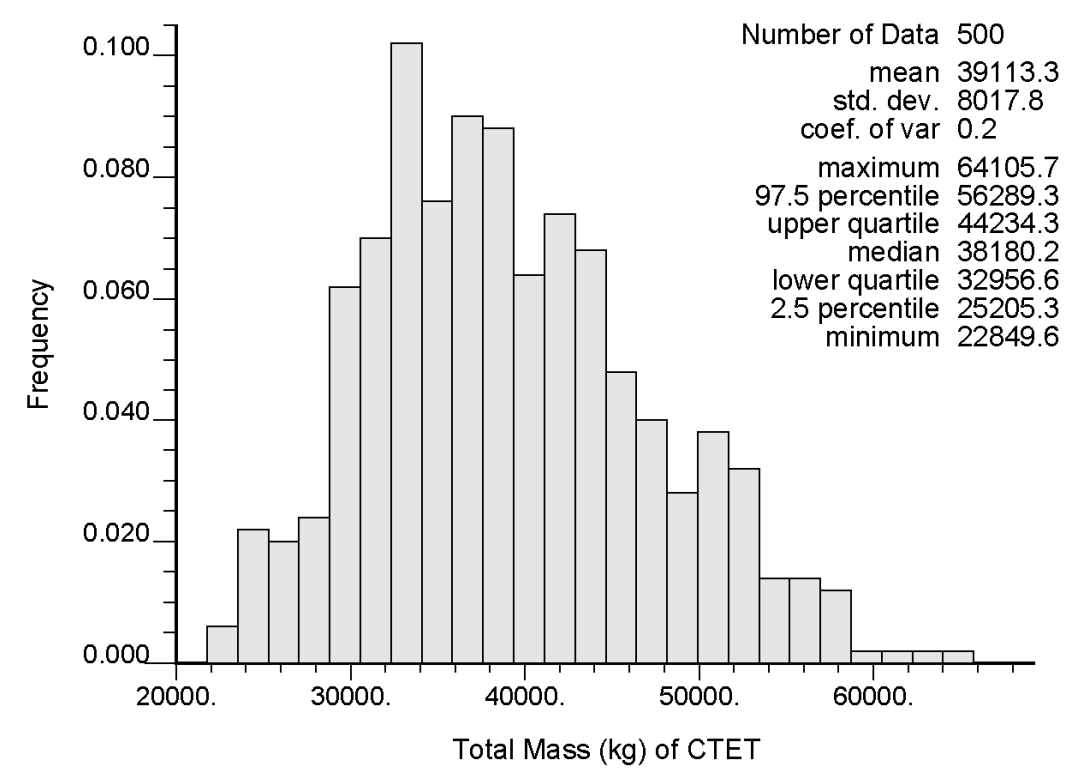

Figure 3.3. Estimated Mass of CTET in the 200-UP-1 Operable Unit. Calculated from the simulations of CTET concentration based on the $3 \mathrm{D}$ variogram model.

\subsection{Estimated Mass of CTET Present Before Abiotic Degradation}

The estimated mass of CTET discussed in Sections 3.1-3.3 was converted to estimates of the total amount of CTET that would have been present originally in the aquifer in order to account for the current inventory, assuming that abiotic degradation had taken place since the CTET originally entered the 
aquifer with an assumed average entry date of 1973 (Murray et al. 2007, Appendix). The resulting estimate of the total amount of CTET represented by the inventory estimates for the total study area (Table 3.4) suggests that approximately $160,000 \mathrm{~kg}$ of CTET would need to have entered the aquifer to account for the current estimate of the existing inventory in the aquifer. This is an $11.4 \%$ increase from the average estimate of the original mass of CTET reported by Murray et al. (2007, Figure 2.24).

Table 3.4. Summary Statistics of Estimated Original Total Mass of CTET Present in the Aquifer Before Its Abiotic Degradation over Time by Hydrolysis

\begin{tabular}{lccr}
\hline & & \multicolumn{3}{c}{ Total Mass (kg) } \\
\cline { 2 - 4 } \multicolumn{1}{c}{ Statistic } & Total Study Area & $200-$ ZP-1 OU & 200-UP-1 OU \\
\hline Mean & $159,966.2$ & $107,770.2$ & $52,196.0$ \\
Standard error & 1260.3 & 939.8 & 529.9 \\
Median & $156,886.7$ & $105,584.3$ & $50,913.6$ \\
Standard deviation & $28,180.2$ & $21,014.9$ & $11,849.5$ \\
Kurtosis & 0.0 & 0.3 & 0.5 \\
Skewness & 0.5 & 0.5 & 0.6 \\
Range & $158,176.8$ & $139,947.8$ & $72,632.1$ \\
Minimum & $97,864.9$ & $57,148.4$ & $28,084.1$ \\
Maximum & $256,041.6$ & $197,096.2$ & $100,716.2$ \\
Count & 500 & 500 & 500 \\
\hline
\end{tabular}





\subsection{References}

Cantrell KJ, RJ Serne, and GV Last. 2003. Hanford Contaminant Distribution Coefficient Database and Users Guide. PNNL-13895 Rev. 1, Pacific Northwest National Laboratory, Richland, Washington.

Deutsch CV and AG Journel. 1998. GSLIB: Geostatistical Software Library and User's Guide, 2nd Edition. Oxford University Press, New York.

Gilbert RO. 1987. Statistical Methods for Environmental Pollution Monitoring. Van Nostrand Reinhold, New York.

Goovaerts P. 1997. Geostatistics for Natural Resources Evaluation. Oxford University Press, New York.

Hartman MJ and WD Webber (eds). 2008. Hanford Site Groundwater Monitoring for Fiscal Year 2007. DOE/RL-2008-01, Rev. 0, U.S. Department of Energy, Richland Operations Office, Richland, Washington.

Murray CJ and Y Bott. 2008. Spatial Analysis of Contaminants in 200 West Area Groundwater in Support of the 200-ZP-1 Operable Unit Pre-Conceptual Remedy Design. PNNL-18100, Pacific Northwest National Laboratory, Richland, Washington.

Murray CJ, Y Bott, and MJ Truex. 2007. Geostatistical Analyses of the Persistence and Inventory of Carbon Tetrachloride in the 200 West Area of the Hanford Site. PNNL-16509, Pacific Northwest National Laboratory, Richland, Washington.

Oostrom M, ML Rockhold, PD Thorne, GV Last, and MJ Truex. 2004. Three-Dimensional Modeling of DNAPL in the Subsurface of the 216-Z-9 Trench at the Hanford Site. PNNL-14895, Pacific Northwest National Laboratory, Richland, Washington.

Oostrom M, ML Rockhold, PD Thorne, GV Last, and MJ Truex. 2006. Carbon Tetrachloride Flow and Transport in the Subsurface of the 216-Z-18 Crib and 216-Z-1A Tile Field at the Hanford Site: Multifluid Flow Simulations and Conceptual Model Update. PNNL-16198, Pacific Northwest National Laboratory, Richland, Washington.

Oostrom M, TW Wietsma, MA Covert, and VR Vermeul. 2007. "Zero-Valent Iron Emplacement in Permeable Porous Media Using Polymer Additions." Ground Water Monitoring and Remediation 27(1):122-130.

Riley RG, DS Sklarew, CF Brown, PM Gent, JE Szecsody, AV Mitroshkov, and CJ Thompson. 2005. Carbon Tetrachloride and Chloroform Partition Coefficients Derived from Aqueous Desorption of Contaminated Hanford Sediments. PNNL-15239, Pacific Northwest National Laboratory, Richland, Washington.

Szecsody JE, JS Fruchter, JL Phillips, ML Rockhold, VR Vermeul, MD Williams, BJ Devary, and Y Liu. 2005. Effect of Geochemical and Physical Heterogeneity on the Hanford 100D Area In Situ Redox 
Manipulation Barrier Longevity. PNNL-15499 Rev. 1, Pacific Northwest National Laboratory, Richland, Washington.

Thorne PD, MP Bergeron, MD Williams, and VL Freedman. 2006. Groundwater Data Package for Hanford Assessments. PNNL-14753 Rev. 1, Pacific Northwest National Laboratory, Richland, Washington.

Truex MJ, CJ Murray, CR Cole, RJ Cameron, MD Johnson, RS Skeen, and CD Johnson. 2001. Assessment of Carbon Tetrachloride Groundwater Transport in Support of the Hanford Carbon Tetrachloride Innovative Technology Demonstration Program. PNNL-13560, Pacific Northwest National Laboratory, Richland, Washington.

Wellman DM, RG Riley, EA Rodriguez, AV Mitroshkov, and KE Parker. 2007. Carbon Tetrachloride Partition Coefficients Measured by Aqueous Sorption to Hanford Sediments from Operable Units 200UP-1 and 200-ZP-1. PNNL-16100, Rev. 1, Pacific Northwest National Laboratory, Richland, Washington.

Williams BA, FA Spane, VJ Rohay, and DB Erb. 2005. "Characterization of the Vertical Distribution of Carbon Tetrachloride Contamination in Hanford Site Groundwater." Presented to the Washington State 5th Annual Hydrogeology Symposium, April 12, 2005, Tacoma, Washington. Abstract accessed online at http://www.ecy.wa.gov/events/hg/PastSymposia/abstracts2005.pdf (December 2008). 


\section{Distribution}

No. of

Copies

\section{OFFSITE}

M. J. Tonkin

S.S. Papadopulos \& Assoc., Inc.

7944 Wisconsin Avenue

Bethesda, MD 20814

R. Dinicola

U.S. Geological Survey

Washington Water Science Center

934 Broadway, Suite 300

Tacoma, WA 98402

Vista Engineering Technologies LLC

1355 Columbia Park Trail

Richland, WA 99352

Attn: W. Bratton

C. Arola

\section{ONSITE}

\section{DOE-Richland Operations Office}

BL Charboneau

A6-33

JG Morse

AC Tortoso
No. of

Copies

20 CH2M HILL Plateau

Remediation Company

R Biggerstaff $\quad$ E6-35

ME Byrnes E6-44

KM Davis E6-44

WS Elliott E6-44

DB Erb E6-35

GG Kelty E6-35

DS Miller E6-44

K Moser E6-44

RW Oldham E6-35

SW Petersen E6-35

RS Popielarczyk E6-35

VJ Rohay (5) E6-44

AJ Rossi R3-60

SA Simmons E6-44

LC Swanson B6-06

BH Von Bargen R3-19

U.S. Environmental Protection Agency

DA Faulk B1-46

12 Pacific Northwest National Laboratory

GV Last

K6-81

CJ Murray (5) K6-81

M Oostrom K9-33

ML Rockhold K9-36

FA Spane K6-96

MJ Truex K6-96

Hanford Technical Library (2) P8-55 




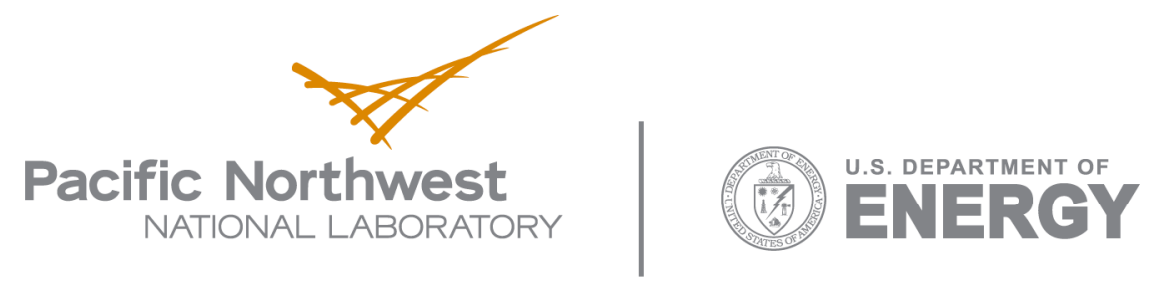

902 Battelle Boulevard

P.O. Box 999

Richland, WA 99352

1-888-375-PNNL (7665)

www.pnl.gov 